\title{
Amaranth proteins foaming properties: Film rheology and foam stability - Part 2
}

\author{
Agustín J. Bolontrade, Adriana A. Scilingo, María C. Añón* \\ Centro de Investigación y Desarrollo en Criotecnología de Alimentos (CIDCA:), Facultad de Ciencias Exactas, UNLP- CONICET-CCT La Plata, calle 47 y 116, La \\ Plata, Argentina.
}

\section{A R T I C L E I N F O}

\section{Article history:}

Received 10 July 2014

Received in revised form

26 September 2014

Accepted 22 October 2014

Available online $\mathrm{xxx}$

\section{Keywords:}

Amaranth proteins

Air-water interface

Film rheology

Foaming properties

\begin{abstract}
A B S T R A C T
In this work the influence of $\mathrm{pH}$ and ionic strength on the stability of foams prepared with amaranth protein isolate was analyzed. The behaviour observed was related to the physico-chemical and structural changes undergone by amaranth protein as a result of those treatments. The results obtained show that foams prepared at acidic $\mathrm{pH}$ were more stable than the corresponding to alkaline $\mathrm{pH}$. At $\mathrm{pH} 2.0$ the foams presented higher times and more volumes of drainage. This behaviour is consistent with the characteristics of the interfacial film, which showed a higher viscoelasticity and a greater flexibility at acidic $\mathrm{pH}$ than alkaline $\mathrm{pH}$ value, which in turn increased by increasing the concentration of proteins in the foaming solution. It is also important to note that the presence of insoluble protein is not necessarily detrimental to the properties of the foam. Detected changes in the characteristics of the interfacial film as in the foam stability have been attributed to the increased unfolding, greater flexibility and net charge of amaranth proteins at acidic conditions.
\end{abstract}

(c) 2014 Elsevier B.V. All rights reserved.

\section{Introduction}

The use of proteins obtained from vegetables is presented as a prospect response to worldwide food needs [1]. For this reason, further information on the functional behaviour of proteins of vegetable origin is needed so that they can be incorporated to a greater variety of products. Amaranth, a pseudocereal growing in the American continent, is an unconventional and interesting source of proteins. It is a C4 plant, whose seeds contain a large amount $(14-17 \%, w / w)$ of high nutritional quality proteins $[2,3]$ and it can grow under soil conditions that are unfavourable to other conventional species of crops.

Many foods are dispersed systems where proteins are used for their surfactant properties, which allow the formation and/or increase their stability. Many authors have studied interfacial properties of proteins over time, understanding that a surfactant-covered interface can be seen as a two-dimension body with its own rheological properties [4-7].

A great challenge is to incorporate amaranth into existing food formulations in order to modify their functional and nutritional qualities, as well as to create entirely new products such as

\footnotetext{
* Corresponding author at: CIDCA calle 47 y 116, 1900 La Plata, Argentina. Tel.: +54 221 4249287; fax: +542214254853.

E-mail address: mcacidca@gmail.com (M.C. Añón).
}

foam-type products. We have already studied the interfacial and emulsifying properties of amaranth proteins at acidic and alkaline pHs. The results obtained clearly showed that amaranth proteins at acidic $\mathrm{pH}$ have a better activity at the oil:water interface and are capable of forming stable emulsions [8]. Recently, we have studied interfacial properties of amaranth proteins. In particular [9], we studied the diffusion, adsorption and rearrangement phenomena occurring at the air-water interface, the relation between these phenomena and the protein structure and the influence of these factors in the formation of foams formulated with them. We have found that the acidic $\mathrm{pH}$ (treatment at $\mathrm{pH} 2$, together with the increase of ionic strength) favours adsorption of proteins, reduces the time for a rearrangement and improves the foaming properties increasing foaming capacity and forming more dense and homogeneous foams [9]. The aim of this work was study the capability of amaranth proteins to stabilize foams under different $\mathrm{pH}$ and ionic strength conditions analysing the rheological behaviour of air-water interface; with the final objective of using the amaranth proteins in foam type-products.

\section{Materials and methods}

\subsection{Plant materials and flour preparation}

Seeds of Amaranthus hypochondriacus, (cultivar 9122) were obtained from Estación Experimental of Instituto Nacional de 
Tecnología Agropecuaria (INTA), Anguil, La Pampa, Argentina. Seeds were ground and sieved through a $0.092 \mathrm{~mm}$ mesh in Facultad de Ciencias Agrarias y Forestales, Universidad Nacional de La Plata. The resulting flour was defatted with hexane at $4{ }^{\circ} \mathrm{C}$ for $24 \mathrm{~h}$ ( $100 \mathrm{~g} / \mathrm{l}$ suspension) under continuous stirring, dried at room temperature and stored at $4{ }^{\circ} \mathrm{C}$ until used. The protein content $(19.8 \pm 0.2 \%$ wet basis) was determined by the Kjeldahl method [10], $N \times 5.85$ [11].

\subsection{Preparation of amaranth isolates}

The amaranth protein isolate was prepared according to Martínez and Añón [12]. The previously defatted flour was suspended in water in a relation 1:10 and the $\mathrm{pH}$ of the suspension was adjusted to 9.0 by the addition of $2 \mathrm{~N} \mathrm{NaOH}$ solution. The suspension was stirred during $1 \mathrm{~h}$ and then centrifuged at $9000 \times \mathrm{g}$ for $20 \mathrm{~min}$ at $10^{\circ} \mathrm{C}$. The $\mathrm{pH}$ of the supernatant was adjusted to 5.0 with $2 \mathrm{M} \mathrm{HCl}$ and centrifuged at $4{ }^{\circ} \mathrm{C}$ for $20 \mathrm{~min}$ at $9000 \times \mathrm{g}$. The precipitate was suspended in water, neutralized with $0.1 \mathrm{M}$ $\mathrm{NaOH}$ and freeze-dried. The protein content of isolate was $85 \pm 1 \%$ (dry basis) as determined by Kjeldahl method [10], $N \times 5.85$ [11]. The isolates used in this work were prepared at least three times, showing similar properties.

Protein isolates were dispersed at $\mathrm{pH} 2$ in $0.035 \mathrm{M}$ phosphoric acid-diacid phosphate buffer, and at pH 8 in $0.035 \mathrm{M}$ Tris buffer. The ionic strength (IS) was adjusted to 0.5 and 0.06 with $0.5 \mathrm{M} \mathrm{NaCl}$, obtaining four amaranth isolates named AI pH2-highIS, AI pH8highIS, AI pH2-lowIS and AI pH8-lowIS [9].

\subsection{Protein film rheology}

The interfacial rheology of films obtained with solutions in the protein concentration range between $0.001-1.0 \mathrm{~g} / \mathrm{ml}$ was measured by using the automated drop tensiometer (Tracker, IT-Concept. Saint-Clémenttes Places, France). The protein concentrations used were selected according to previous works [8,9]. The bubble was formed in the protein solution and the surface tension over time was calculated based on changes in drop form.

Dilatational rheology studies the interface response to sinusoidal deformations of compression/expansion (change of area but not of form). The interface response to deformation is described by the complex modulus $E^{*}$, which refers to the relation between the response in $\gamma$ for a given relative area deformation.

$E^{*}=\frac{d \gamma}{d A / A}=\frac{d \gamma}{d \ln A}$

$E^{*}$ modulus is a complex number, which can be decomposed in a real part ( $E^{\prime}$, Eq. (2)), called storage modulus - that represents the elastic behaviour of the film - and an imaginary part ( $E^{\prime \prime}$, Eq. (3)), called loss modulus - that represents the viscous component - [13]. For an entirely elastic interface, deformation is in phase with the response. However, it is generally observed that there is a discrepancy defined by an angle $\theta$, which increases with a greater contribution of the viscous component.

$E^{\prime}=|E *| \cos \theta$

$E^{\prime \prime}=|E *| \sin \theta$

$\tan \theta=\frac{E^{\prime \prime}}{E^{\prime}}$

where $\theta$ is the viscous phase angle.

The relative contribution of both components was analyzed by using the parameter $\tan \theta$.

Experimentally, rheological parameters $E^{*}, E^{\prime}, E^{\prime \prime}$ and $\tan \theta$ were assessed during the formation of the interfacial film for a period of $10,800 \mathrm{~s}$. Sinusoidal deformations were made at a frequency of
$100 \mathrm{mHz}$ during $50 \mathrm{~s}$, every $500 \mathrm{~s}$, with an amplitude of $0.1 \Delta \mathrm{A} / \mathrm{A}$ within the lineal viscoelasticity range.

The interfacial rheology of films in a pseudo-equilibrium state was studied using the same automated drop tensiometer. Rheological behaviour of the interface under different deformation frequencies allows analysing relaxation times of the interfacial structure. Tests were carried out $3 \mathrm{~h}$ after the formation of the film. Sinusoidal deformations of amplitude $0.1 \Delta \mathrm{A} / \mathrm{A}$ were performed, covering a frequency range between $5 \mathrm{mHz}$ and $300 \mathrm{mHz}$.

\subsubsection{Foaming properties - foam stability}

The foaming properties of amaranth proteins were determined by conductimetry using the method and device developed by Loisel et al. [14].

Protein dispersions (soluble and insoluble proteins) or protein solutions at $1.0 \mathrm{~g} / \mathrm{l}$ of soluble protein were prepared in the corresponding buffers. Protein solutions were obtained after centrifugation at $10,000 \times g$ during $15 \mathrm{~min}$ at $20^{\circ} \mathrm{C}$. Protein dispersions or protein solutions were placed in the sparging chamber at the base of an acrylic column (length: $27.5 \mathrm{~cm}$, internal and external diameters: 2.4 and $3.0 \mathrm{~cm}$, respectively). Foam was generated by sparging nitrogen gas through porous G4 type glass disc with a pore size of $5-15 \mu \mathrm{m}$, at a rate of $80 \mathrm{ml} / \mathrm{min}$ into $6 \mathrm{ml}$ of the sample during $30 \mathrm{~s}$. The volume of initial or residual liquid under the foam was measured by conductivity through two electrodes located in the sparging chamber. Conductivity values, as a function of time $\left(C_{t}\right)$ and with reference to the conductivity of the buffered test solution $\left(C_{\text {init }}\right)$, were used to calculate half time $\left(t_{1 / 2}\right)$. This parameter is defined as the time elapsed from the bubbling stopped until half of the liquid incorporated to the foam was drained. $\mathrm{VLF}_{10}$ corresponds to the volume of liquid remaining in the foam after $10 \mathrm{~min}$ from the bubbling stopped. This is a parameter, defined in our laboratory, that allows to estimate the foam stability via processes of gas diffusion (disproportionation) and collapse.

The foam destabilization phenomenon was interpreted, as other authors have done [15-17], as two simultaneous processes. On the one hand, the gravitational drainage of the liquid and on the other hand, the diffusion and collapse drainage.

A first order biphasic exponential model (Eq. (5)) was used to fit the experimental data [15] as follows:

$V_{\mathrm{LF}}(t)=V_{\mathrm{g}} e^{\left(-t / \tau_{\mathrm{g}}\right)}+V_{\mathrm{dc}} e^{\left(-t / \tau_{\mathrm{dc}}\right)}$

where the first term refers to the gravitational drainage process ( $\mathrm{g}$ ) and the second to the gas diffusion or disproportionation and collapse drainage processes (dc). With the application of the model, four parameters are adjusted, two correspond to the amplitude of each process $\left(V_{\mathrm{g}}, V_{\mathrm{dc}}\right)$, and two kinetic parameters which correspond to the relaxation time of each process $\left(\tau_{\mathrm{g}}, \tau_{\mathrm{dc}}\right)$. Parameter $V_{\mathrm{LF}}$ for different $t$ was calculated knowing the volume of remaining liquid at time $t\left(V_{\mathrm{LS}}\right)$ by subtracting the volume of liquid at time zero. $V_{\mathrm{LS}}$ and $V_{\mathrm{LSO}}$ values were experimentally obtained from the conductivity data.

The model was adjusted to the experimental data with the OriginPro 8 SR0 programme (Origin Lab Corporation, Northampton, MA 01060 USA). Each experiment was performed three times.

\subsubsection{Statistical analysis}

The least significant difference (LSD) test (after analysis of variance, ANOVA) was used to identify pairwise differences between means. Significance was determined at $p<0.05$. 

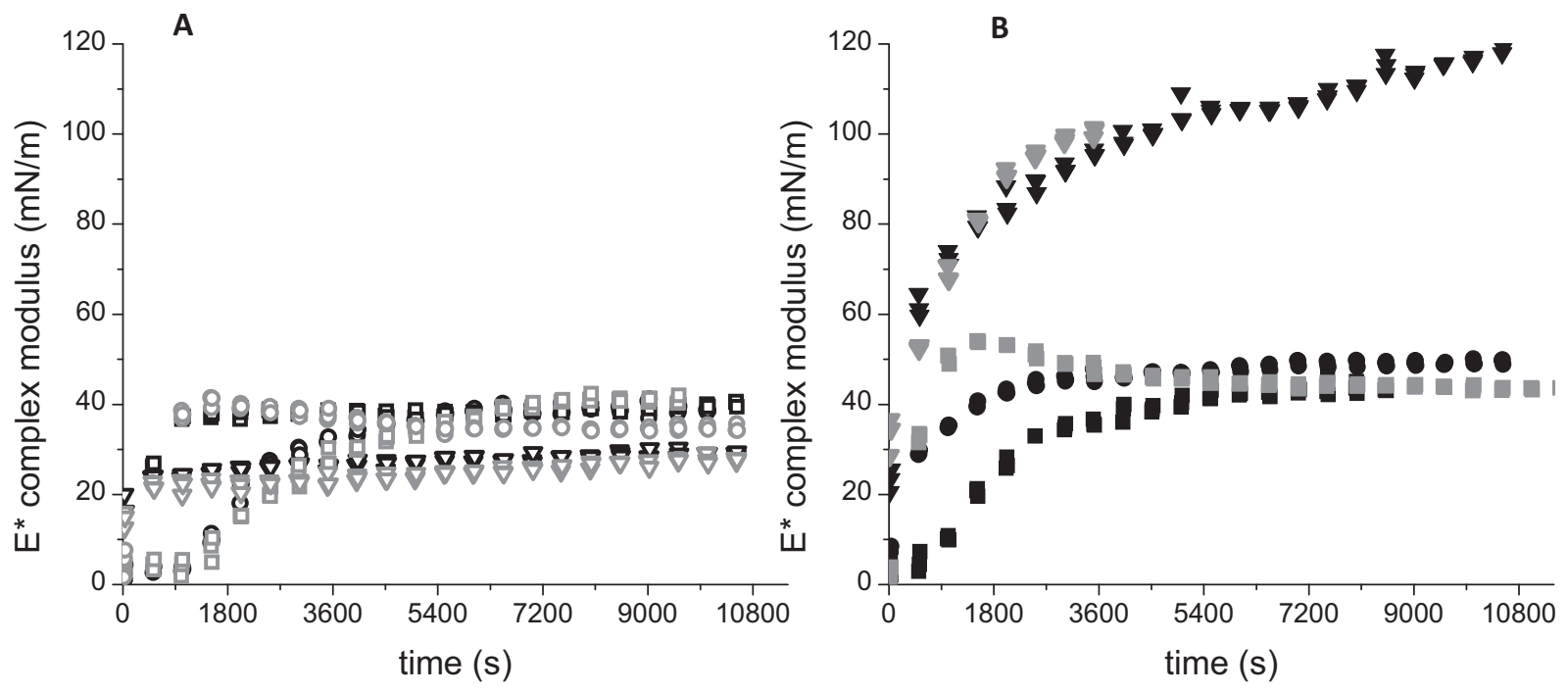

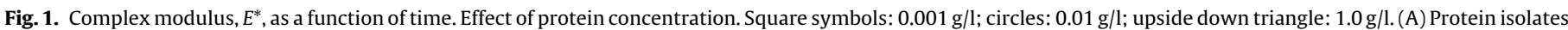

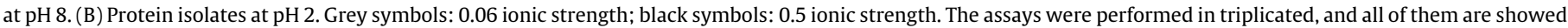
in the figure. The points of each assay overlapped.

\section{Results}

\subsection{Interfacial viscoelasticity}

Modulus $E^{*}$ is a parameter that allows to assess the interface resistance to deformation, which is generally associated to its solid character [7]. Fig. 1 shows the variation of the dilatational modulus over time for amaranth proteins in the air/water interface, as a function of the $\mathrm{pH}$ (Fig. 1 A, pH 8 and $\mathrm{B}, \mathrm{pH} 2$ ) and the ionic strength. Under all $\mathrm{pH}$ and IS conditions tested, an increase of the complex modulus with the ageing time was observed. This increase can be attributable to the adsorption, penetration and rearrangement of the proteins in the interface.

At $\mathrm{pH} 8$ and adsorption times higher than 3600 s, no differences were observed between the employed IS conditions but there were differences detected when the protein concentration was modified. At $\mathrm{pH} 8$ and $0.001 \mathrm{~g} / \mathrm{l}$ of protein bulk concentration, $E^{*}$ started to increase $1000 \mathrm{~s}$ after the interface was formed while at greater concentrations of 0.01 and $1.0 \mathrm{~g} / \mathrm{l}$, the increase takes place faster. This behaviour is similar to that described for other proteins [18,19]. Three hours after the interface was formed, and with the lowest protein concentration tested, $E^{*}$ reaches a value of $\sim 40 \mathrm{mN} / \mathrm{m}$, while at $1.0 \mathrm{~g} / \mathrm{l}$, it only increases up to $\sim 28 \mathrm{mN} / \mathrm{m}$, which suggests the existence, at a high protein concentration, of different molecular rearrangements such as structural transitions or protein film collapse at the air-water interface.

At $\mathrm{pH} 2$, no differences were observed between the two tested IS conditions. When increasing protein concentration, $E^{*}$ increases faster. At $0.001 \mathrm{~g} / \mathrm{l}$ and $0.01 \mathrm{~g} / \mathrm{l}, 3 \mathrm{~h}$ after the interface was formed, the $E^{*}$ value reaches $\sim 46 \mathrm{mN} / \mathrm{m}$, while at $1.0 \mathrm{~g} / \mathrm{l}$, unlike what has previously been observed at $\mathrm{pH} 8$, the interface improves its resistance to deformation reaching $E^{*}$ values of $116 \mathrm{mN} / \mathrm{m}$. This would imply greater adsorption of proteins at the interface and greater interfacial interactions.

Given that the dilatational modulus is related to the quantity of protein adsorbed in the air-water interface, data corresponding to $E^{*}$ might be normalized in a master curve $E^{*}$ vs. $\pi$ [20]. Fig. 2a shows, as an example, this kind of curve for AI pH8-lowIS sample. The slope of this graphic is a parameter that allows assessing the flexibility of molecules in the interface, understanding that the lower the value of the slope; the more flexible the interface is [21,22]. The calculated slope values suggest the formation of more flexible interfaces at lower $\mathrm{pH}$ and greater IS. Under assessed conditions, the following slope values were obtained: 7.2 (AI pH8-lowIS), 5.0 (AI pH8-highIS), 4.3 (AI pH2-lowIS), 3.0 (AI pH2-highIS). These values are similar to those evidenced for other proteins such as $\beta$-lactoglobulin, (with a value of 7.5; [23]) and $\kappa$-casein (with a value of 4.0; [24]). According to Benjamins and Lucassen-Reynders [24], more flexible proteins usually produce a more compressible and less cohesive films with lower elasticity than more compacted proteins.

The normalization of $E^{*}$ vs. $\pi$ was only possible for the samples corresponding to $\mathrm{pH} 8$ both at high and low ionic strength. At acidic $\mathrm{pH}$, at both ionic strengths (AI pH2-lowIS and AI pH2-highIS), the curves corresponding to the highest protein concentration tested $(1.0 \mathrm{~g} / \mathrm{l})$ provided a line of $E^{*} \mathrm{vs} . \pi$ different from the rest of the concentration (Fig. 2b), which suggests that under these conditions proteins join at the interface with a different degree of association.

In previous studies $[8,9]$, we have demonstrated that treating proteins at acidic $\mathrm{pH}$ leads not only to its dissociation and denaturalization with subsequent reduction of molecular mass and the increase of their flexibility, but also to the activation of an active aspartic protease that accompanies the proteins. This group of structural modifications might be responsible for the greater flexibility of the interface obtained at acidic $\mathrm{pH}$ as well as for the different degrees of association with which proteins are adsorbed onto the interface, depending on the conditions of the environment.

Fig. 3 shows the variation of the $\tan \theta$ during the formation of the interfacial film. At all $\mathrm{pH}$ and IS conditions tested, when the protein concentration in the solution is increased, we observed an increase in the viscous component reaching values of $\tan \theta$ higher or equal to 0.6. In previous studies [9], we have demonstrated that the increase of protein concentration in the solution leads to an increase of the adsorbed protein at the interface, which could brings about a greater interchange of protein molecules between the interface and the solution, and consequently, an increase of the viscous component [7]. At lower protein concentrations, 0.01 and $0.001 \mathrm{~g} / \mathrm{l}$ for AI pH8-lowIS, AI pH8-highIS and AI pH2-lowIS, the values of the $\tan \theta$ are lower or equal to 0.2 , which suggests the formation of more elastic films with a reduced contribution of the viscous component.

In the case of AI pH2-highIS, separated data populations according to the interfacial concentration of proteins can be detected, which may be due to a higher rate of the relaxation processes in the thicker interfaces in comparison to the thinner ones. It can 
A



120

B

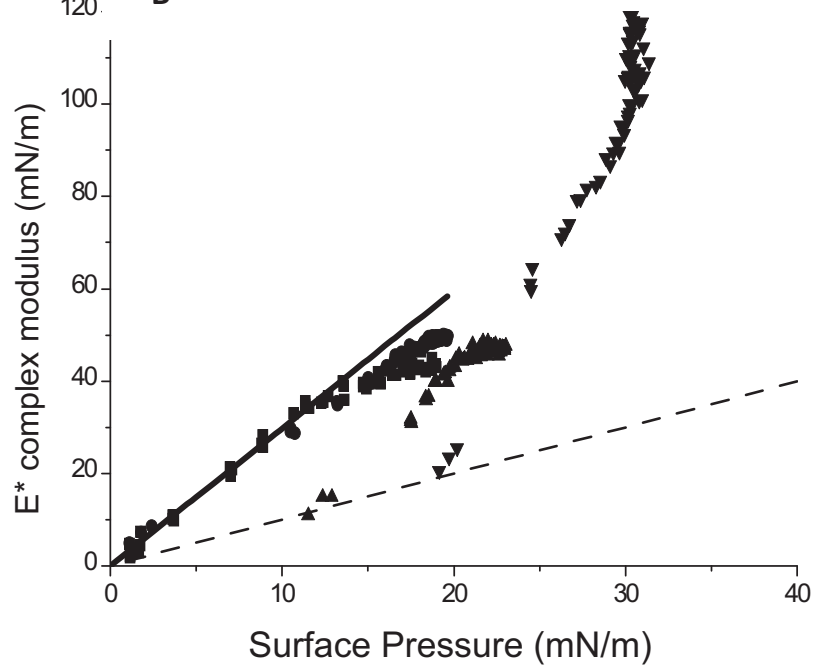

Fig. 2. Complex modulus, $E^{*}$, as a function of surface pressure, $\pi$. (A) AI pH8-lowIS. (B) AI pH2-highIS. Square symbols: $0.001 \mathrm{~g} / \mathrm{l}$; circles: $0.01 \mathrm{~g} / \mathrm{l}$; upside down triangle: $1.0 \mathrm{~g} / \mathrm{l}$.

be observed that as the protein concentration increases, values of $\tan \theta$ increase at values of $\pi$ of $10-20 \mathrm{mN} / \mathrm{m}$ to decrease when the interfacial pressure increases $[25,26]$.

During the interfacial film formation, we observed a relative increase of the complex modulus for the different protein concentrations tested. This increase is well defined for samples of $\mathrm{pH} 2$ at high and low IS (Fig. 1b). The increase of the viscoelastic modulus of
$20 \mathrm{mN} / \mathrm{m}$ at $120 \mathrm{mN} / \mathrm{m}$ for $\pi$ values of $20-30 \mathrm{mN} / \mathrm{m}$ (Fig. $2 \mathrm{~b}$ ) could be attributable to a restructuring and rearrangement of the interface protein with modification of the relaxation mechanisms that take place at an interface level, which contributes to greater elasticity of the film (Fig. 3) [27]. Moreover, the contribution of increased protein-protein interaction cannot be ruled out.

According to Lucassen and van den Tempel [28], the relationship between the elastic and the viscous components of the dilatational modulus depends on the frequency applied to the interface. Normally, a decrease in the shift of the response to the deformation with the increase of the frequency is detected. This phenomenon is due to the decrease of the cycle time of deformation below the necessary time so that certain relaxation processes can happen. Three hours after the interface was formed, the interfacial film was subjected to sinusoidal deformations $\delta A / A=0.1$ in the frequencies range $5-300 \mathrm{mHz}$. In the case of AI pH8-lowIS and AI pH8-highIS (Fig. 4), the viscoelastic modulus fell slightly when the protein concentration of the solution was increased from 0.01 to $1.0 \mathrm{~g} / \mathrm{l}$ in the whole frequencies range tested, while the value of $\tan \theta$ decreased, suggesting a decrease of the interfacial viscosity (Fig. 4, insert). At pH 2 (Fig. 5) a similar behaviour to that described at $\mathrm{pH} 8$, was evidenced. At frequencies above $150 \mathrm{mHz}$, a critical increase in the deformation resistance was detected, with an evident increase in the interfacial elasticity. At this $\mathrm{pH}$, a faster relaxation processes than at $\mathrm{pH} 8$, evidenced by the decrease of the $\tan \theta$ at greater deformation frequencies, was also observed (Fig. 5, insert).

\subsection{Stability of formed foams}

Different mechanisms such as the gravitational drainage, disproportionation and collapse are involved in the destabilization of foam. These mechanisms cannot be separated over time, with the aim of analysing the stability of foams formed by sparging, we have determined the mean time of the foam $\left(t_{1 / 2}\right)$ and the volume of liquid remaining in the foam after $10 \mathrm{~min}\left(\mathrm{VLF}_{10}\right)$. Data are shown in Table 1 . Values of $t_{1 / 2}$ detected for foams prepared with the fraction of soluble protein showed a significant difference between the two levels of $\mathrm{pH}$ and the IS tested. Foams formed at $\mathrm{pH} 2$ were more stable than those prepared at pH 8, particularly at high IS. On the other hand, foams prepared with the soluble fraction of AI pH8-lowIS, AI pH8-highIS and AI pH2-highIS showed greater stability than those formed with the same concentration of total protein (soluble protein + insoluble protein), as it would be expected given the contribution of the insoluble fraction. However, the foam formed with a total dispersion of AI pH2-lowIS presented a greater $t_{1 / 2}$ than that corresponding to the foam prepared with the soluble fraction. Apparently, the presence of a low content of insoluble protein (Al $\mathrm{pH} 2$-lowIS, 13\%, w/w of insoluble protein) favours the stability of the foam, while high content of insoluble protein (AI pH2-highIS, $74.7 \% \mathrm{w} / \mathrm{w}$ of insoluble protein) would favour the development of destabilization mechanisms (Table 1). A low amount of insoluble protein may act as a physical barrier at the interface between

Table 1

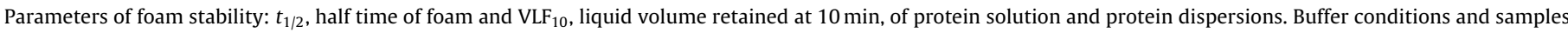
solubility. Values \pm standard deviation.

\begin{tabular}{|c|c|c|c|c|c|c|c|}
\hline \multirow[t]{2}{*}{ Samples } & \multicolumn{2}{|c|}{ Buffer conditions } & \multirow[t]{2}{*}{$\% S^{a}$} & \multicolumn{2}{|l|}{$t_{1 / 2}(\mathrm{~s})^{\mathrm{a}}$} & \multicolumn{2}{|l|}{$\operatorname{VLF}_{10}(\mathrm{ml})^{\mathrm{a}}$} \\
\hline & $\mathrm{pH}$ & IS & & $\begin{array}{l}\text { Protein solution } \\
1 \mathrm{mg} / \mathrm{ml}\end{array}$ & $\begin{array}{l}\text { Protein dispersion } \\
1 \mathrm{mg} / \mathrm{ml}\end{array}$ & $\begin{array}{l}\text { Protein solution } \\
1 \mathrm{mg} / \mathrm{ml}\end{array}$ & $\begin{array}{l}\text { Protein dispersion } \\
1 \mathrm{mg} / \mathrm{ml}\end{array}$ \\
\hline AI pH8-lowIS & & 0.06 & $70 \pm 4$ & $36 \pm 7 a b$ & $28 \pm 1 a$ & $0.8 \pm 0.1 b c$ & $0.70 \pm 0.03 b$ \\
\hline AI pH8-highIS & 8 & 0.5 & $59 \pm 1$ & $45 \pm 6 b$ & $36 \pm 8 a$ & $0.3 \pm 0.2 \mathrm{a}$ & $0.3 \pm 0.1 \mathrm{a}$ \\
\hline AI pH2-lowIS & & 0.06 & $87 \pm 3$ & $62 \pm 1 c$ & $74 \pm 2 d$ & $0.90 \pm 0.08 c$ & $1.15 \pm 0.07 d$ \\
\hline AI pH2-highIS & 2 & 0.5 & $25.3 \pm 0.4$ & $85 \pm 1 d$ & $30 \pm 3 a$ & $0.50 \pm 0.06 b$ & $0.2 \pm 0.1 a$ \\
\hline
\end{tabular}

$\%$ : Percentage solubility.

In each parameter different letters indicate significantly different values $(p<0.05)$.

a Assay made at least in triplicate. 



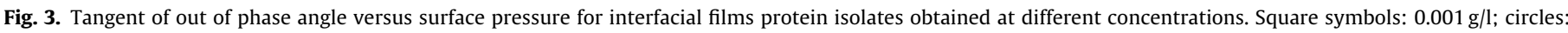

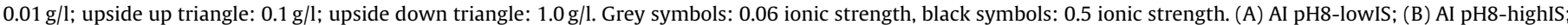
(C) AI pH2-lowIS and (D) AI pH2-highIS. Grey lines in the last panel were included to guide the eye.

bubbles without interfering with the soluble proteins anchored at the interface.

Foams prepared with soluble protein showed different $\mathrm{VLF}_{10}$ values depending on the $\mathrm{pH}$ and IS of the sample (those prepared with AI pH8-lowIS, AI pH8-highIS and AI pH2-lowIS Table 1), retaining higher quantity of liquid. As in the case of $t_{1 / 2}$, the presence of insoluble protein negatively affected the stability of the foam formed with AI pH2-highIS, while at low IS and equal pH (AI pH2lowIS), the effect of this fraction was favourable. This difference may be attributable both to the difference in the quantity of insoluble protein present in both samples and the quality of the proteins present.

When the performance of amaranth proteins was compared to $\beta$ - lactoglobulin, a protein with recognized foaming properties, it was observed that amaranth proteins presented less stable foams at $\mathrm{pH} 8(59.1 \pm 5$, and $80 \pm 5$ for AI pH8-lowIS and AI pH-highIS $)$ than $\beta$ - lactoglobulin. At acidic $\mathrm{pH}$, the stability of both foams was similar over time $(81 \pm 4)$. Adjustment of the obtained experimental data to a biphasic exponential model of first order facilitated the interpretation of the foam destabilization process, separating it into two simultaneous processes: the gravitational drainage and the inter-bubble gas diffusion which lead to disproportionation and collapse of them. This simplification has also been assumed by other authors $[15,16]$, considering these two mechanisms as the main responsible ones for foam destabilization [29]. The model has allowed adjusting the parameter of the drained liquid volume in each process and the speed at which it occurs. Out of all the liquid incorporated into the foam, we could observe - in the case of more unstable foams - a tendency to a greater elimination of liquid due to the gravitational drainage process in comparison to the disproportionation and collapse drainage (Table 2).

To analyze the rate at which such processes take place, the relaxation times of the model $\left(\tau_{\mathrm{g}}\right.$ and $\tau_{\mathrm{dc}}$ ) were adjusted to the experimental data. In first order equations, the factor $1 / \tau$ corresponds to the speed constant, so greater relaxation time implies lower speed of the process. When comparing both drainage processes, it was observed that relaxation times of gravitational drainage (Table 2) were a lower order of magnitude than relaxation times through disproportionation and collapse (Table 2). This would be in line with the findings of Yu and Damodaran [17], when they reported that the magnitude of the foam decay through interbubble gas diffusion (disproportionation) is only significant when it is under the lamella critical thickness reached through the liquid gravitational drainage.

Relaxation times in the gravitational drainage process were lower at $\mathrm{pH} 8$ than at $\mathrm{pH} 2$. The difference between the two conditions of IS was significant at $\mathrm{pH} 2$, presenting a greater relaxation time at high IS (Table 2). Lower relaxation time conditions - in consequence greater drainage rate - coincided with a greater proportion of liquid eliminated through this process, which in turn led to a lower value of $t_{1 / 2}$ (Table 1 ). This lower stability at $\mathrm{pH} 8$ in comparison to $\mathrm{pH} 2$ coincided with a lower interfacial elasticity (Fig. 3).

The remaining liquid in the foam that is not eliminated through gravitational drainage is attributable to the drainage process through disproportionation and collapse. As we have already mentioned, disproportionation and collapse is a process that occurred at a lower order of magnitude than the gravitational drainage, 
Table 2




at least in triplicated.

\begin{tabular}{|c|c|c|c|c|c|c|}
\hline \multirow[t]{2}{*}{ Samples } & \multicolumn{2}{|c|}{ Percentage of drainage (\% volume) } & \multicolumn{2}{|c|}{ Relaxation time (s) } & \multicolumn{2}{|c|}{$\begin{array}{l}\text { Percentage of drained liquid at } \\
\text { time } t_{1 / 2}\end{array}$} \\
\hline & $\begin{array}{l}\text { Gravitational } \\
\text { drainage }\left(V_{\mathrm{g}}\right)\end{array}$ & $\begin{array}{l}\text { Disproportion and } \\
\text { collapse drainage }\left(V_{\mathrm{dc}}\right)\end{array}$ & $\tau_{\mathrm{g}}$ & $\tau_{\mathrm{dc}}$ & $\% V t_{1 / 2 \mathrm{~g}}$ & $\% V t_{1 / 2 \mathrm{dc}}$ \\
\hline AI pH8-lowIS & $67.4 \pm 0.1 b$ & $32.6 \pm 0.1 \mathrm{~b}$ & $35 \pm 2 a$ & $722 \pm 98 a$ & 97 & 3 \\
\hline AI pH8-highIS & $58 \pm 3 a$ & $42 \pm 3 a$ & $35 \pm 2 a$ & $341 \pm 42 b$ & 89 & 11 \\
\hline AI pH2-lowIS & $57 \pm 3 a$ & $43 \pm 3 a$ & $42 \pm 1 b$ & $688 \pm 131 a$ & 92 & 8 \\
\hline AI pH2-highIS & $53.2 \pm 0.2 a$ & $46.8 \pm 0.2 \mathrm{a}$ & $56 \pm 4 c$ & $405 \pm 49 b$ & 82 & 18 \\
\hline
\end{tabular}

In each column different letters indicate significantly different values $(p<0.05)$.

$V t_{1 / 2 \mathrm{~g}}$ : Drained liquid by gravitational drainage.

$V t_{1 / 2 \mathrm{dc}}$ : Drained liquid by disproportion and collapse drainage.

therefore, the greatest proportion of liquid drained through disproportion and collapse would imply a slower drainage generating more stable foams.

When analysing the relaxation times of this process, no significant differences with the $\mathrm{pH}$ were observed, However; such times were found to be influenced by the IS, being those foams obtained with low IS more stable. This lower rate of drainage through
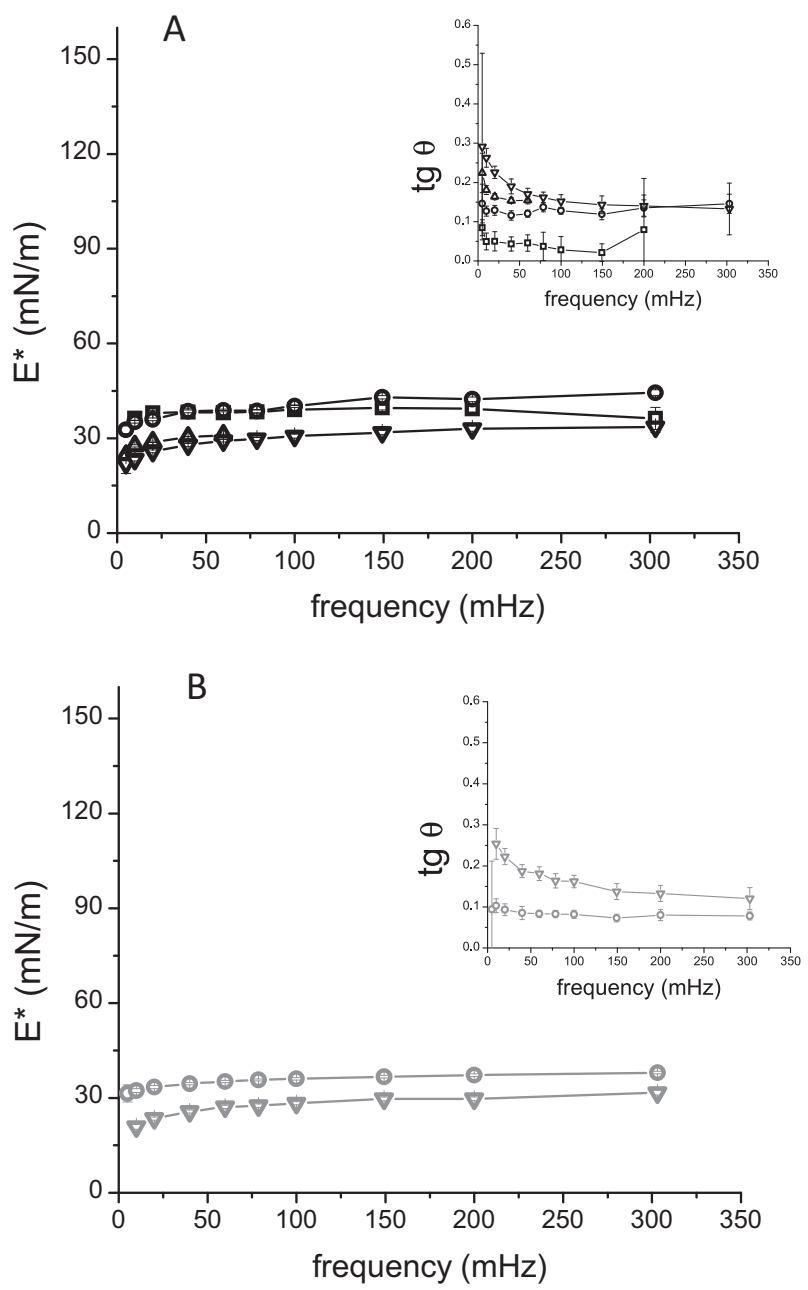

Fig. 4. Complex modulus versus deformation frequency of the interfacial films prepared with AI pH8, after three hours have formed, at different protein concentrations. Square symbols: $0.001 \mathrm{~g} / \mathrm{l}$; circles: $0.01 \mathrm{~g} / \mathrm{l}$; upside up triangle: $0.1 \mathrm{~g} / \mathrm{l}$; upside down triangle: $1.0 \mathrm{~g} / \mathrm{l}$. (A) 0.5 ionic strength, black symbols. (B) 0.06 ionic strength, grey symbols. In inserts: $\tau_{\mathrm{g}} \theta$ vs. frequency. Error bars indicate standard deviation of three assays. disproportionation and collapse may be due to a greater thickness of the lamella at low IS, which would retard the gas diffusion through the lamella and the subsequent disproportionation and collapse. At low IS, there is greater electrical repulsion between the lamella interfaces, a characteristic that would limit its slimming. The latter process not only favours gas diffusion among bubbles

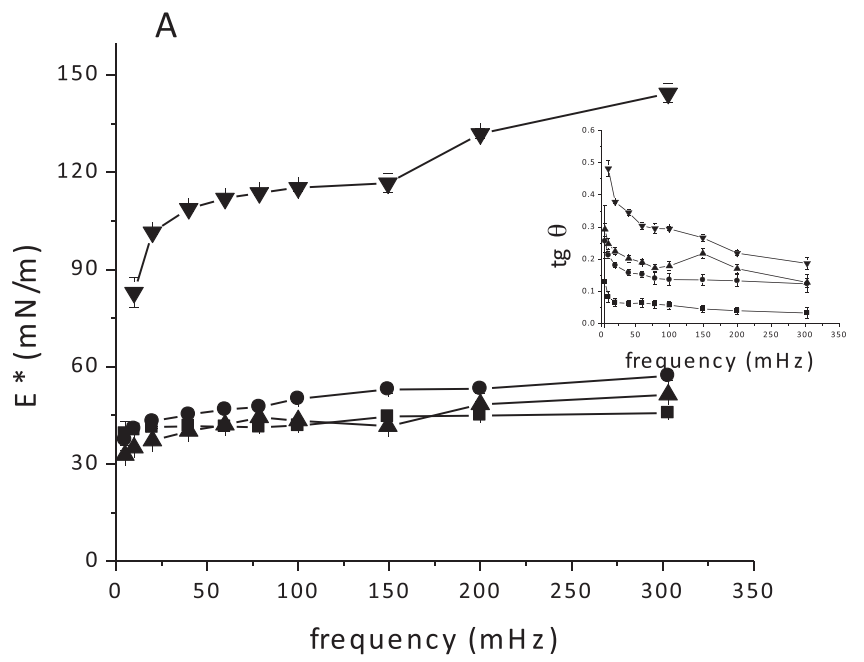

B

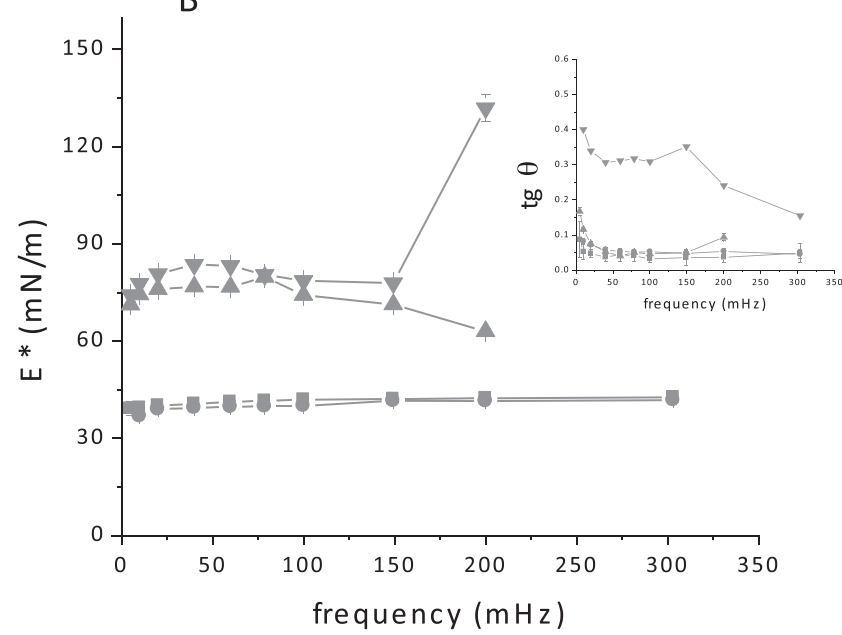

Fig. 5. Complex modulus versus deformation frequency of the interfacial films prepared with $\mathrm{AI}$ pH2, after three hours have formed, at different protein concentrations. Square symbols: $0.001 \mathrm{~g} / \mathrm{l}$; circles: $0.01 \mathrm{~g} / \mathrm{l}$; upside up triangle: $0.1 \mathrm{~g} / \mathrm{l}$; upside down triangle: $1.0 \mathrm{~g} / \mathrm{l}$. (A) 0.5 ionic strength, black symbols. (B) 0.06 ionic strength, grey symbols. In inserts: $\tau_{\mathrm{g}} \theta$ vs. frequency. Error bars indicate standard deviation of three assays. 
but also increases the chances of forming pores in the lamella which allow free flow of gas.

This slower rate in the disproportionation and collapse processes is related to the greater quantity of liquid remaining in the foam 10 min after the bubbling stopped (Table 1 ), regardless of the gravitational drainage rate.

Previous works performed in our laboratory have clearly shown that amaranth storage proteins suffer important structural changes at $\mathrm{pH}$ 2. Such changes include: a decrease of its molecular mass due to the dissociation processes and due to the actions of an endoprotease, unfolding of the protein and increase in its superficial hydrophobicity and net load $[8,9,30]$. Such modifications favourably influence the ability to form foams given that the acidic $\mathrm{pH}$ favours the amaranth protein adsorption process and reduces the rearrangement of molecules in the air/water interface leading to a greater initial speed of air incorporation to the foam and the formation of thick and homogeneous foams [9].

The results obtained in this work also indicate that $\mathrm{pH} 2$ favours the stability of the foams formed, in comparison to those obtained at $\mathrm{pH} 8$; this effect was observed both at an interface level and in the bulk.

Regarding foam stability, elasticity of the film of the adsorbed protein on the bubbling surface has been described as one of the characteristics of the interface with the biggest impact [31-34]. The destabilization process, in general terms, is related to the resistance of the film to undergo deformation over time. In our experiments, it was possible to observe a viscoelastic modulus that was greater at $\mathrm{pH} 2$ than at $\mathrm{pH} 8$, a phenomenon that is expected for foams of greater stability.

The increase of protein concentration in the bulk solution allowed to detect an increase in the viscoelastic modulus $\left(E^{*}\right)$. The increase of the concentration from 0.1 to $1 \mathrm{~g} / \mathrm{l}$ had a different impact at each tested $\mathrm{pH}$, detecting an increase of $E^{*}$ at $\mathrm{pH} 2$ and a decrease at $\mathrm{pH}$ 8. No effect of the IS was detected at any of the tested pHs.

Given that the increase of protein concentration leads to an increase of the contribution of the viscous component of the elastic modulus, it is expected that a rapid incorporation of protein to the interface take place, kinetically hampering the intermolecular rearrangement. Another feasible alternative would be a greater interchange of proteins between the interface and the bulk solution, which would provide the interfacial film with a more viscous character. However, with the ageing of the film, a greater contribution of the elastic component to the viscoelastic modulus was observed, which would be due to the interfacial rearrangement and interaction between protein molecules.

Once the film was formed, the rheology studies performed in this work have shown a more flexible interface at $\mathrm{pH} 2$ than at $\mathrm{pH} 8$, and at IS 0.5 than at IS 0.06 . This behaviour may be due to the greater proportion of proteins/peptides of low molecular size present at acidic $\mathrm{pH}$, a result of the above mentioned structural changes. The assays performed at different frequencies allowed us to assess the presence of relaxation processes of higher speed at $\mathrm{pH} 2$ than at $\mathrm{pH} 8$, such as the reorientation of protein molecules after adsorption, internal rearrangements, molecular compression and the formation of multi-film structures that contribute to the viscosity of the interface.

Our results have also shown that foams formed at acidic $\mathrm{pH}$ are more stable, in terms of mean time of drainage and volume of remaining liquid in the foam after $10 \mathrm{~min}$ of having been formed, than those prepared at $\mathrm{pH} 8$, particularly at high IS. The adjustment of the experimental data making use of a biphasic exponential model of first order [15] allowed to determine that less stable foams, obtained as was previously explained at $\mathrm{pH} 8$, had a greater tendency to lose liquid through gravitational drainage, displaying much shorter relaxation times than those corresponding to disproportionation and collapse processes.
Interfacial elasticity is also a key element in the different stages of destabilization process. A fall in the drainage due to the effect of the plateau border in elastic interfaces [35] has been described, which is in line with our results, where foams at $\mathrm{pH} 2$ that showed greater interfacial elasticity, also presented a lower speed in the drainage process. It has been demonstrated that the increase of the interfacial viscoelasticity leads to a decrease in the transportation of gas among bubbles, which brings about a fall in the disproportionation process [36] and a rise in the stability through collapse [37]; an effect that, in our case, is evidenced in the foams obtained at low IS, both at $\mathrm{pH} 2$ as at 8 .

Finally, it is worth highlighting the effect of the presence of insoluble particles in the environment where foams are formed. Results indicate that, in general, the presence of insoluble aggregates favours the destabilization of formed foams, except from those foams obtained at $\mathrm{pH}$-lowIS, an effect that could be attributable both to the quantity of insoluble aggregates present and to their physicochemical properties [6].

\section{Conclusions}

The results presented clearly show that the foams made with amaranth proteins at acidic $\mathrm{pH}$ exhibit better stability than those obtained at alkaline pH. Under these conditions more flexible, particularly at low ionic strength, and elastic films were formed. Moreover we have also shown that relaxation phenomena associated with the rearrangement of the protein chains at the interface occur faster at acidic $\mathrm{pH}$. These foams in turn were less sensitive to gravity drainage. A low ionic strength, the foams made both at acid $\mathrm{pH}$ and at alkaline $\mathrm{pH}$ showed less tendency to become unstable by disproportionation and collapse phenomena.

The results obtained provide an interesting opportunity to incorporate amaranth proteins into acid foam-type food, such as dessert stuffing and ice creams, among others.

\section{Acknowledgements}

The authors acknowledge the support of CONICET (Grant PIP 1330) and ANPCyT (Grant PICT 1119) and Universidad de la República, Montevideo, Uruguay for allowing us the use of the tracker tensiometer.

\section{References}

[1] H. Aiking, Trends Food Sci. Technol. 22 (2011) 112.

[2] B. Salcedo-Chávez, J.A. Osuna-Castro, F. Guevara-Lara, J. DominguezDomínguez, O. Paredes-López, J. Agric. Food Chem. 50 (2002) 6515.

[3] S.H. Guzmán-Maldonado, O. Paredes-López, in: J.R. Whitaker, F. Shahidi, A. López-Munguia, R.Y. Yada, G. Fuller (Eds.), Functional properties of proteins and lipids, Am. Chem. Soc., Washington, D.C., 1998, p. 66.

[4] S. Damodaran, A. Paraf, Food Proteins and Their Application, Dekker, New York, 1997.

[5] E. Dickinson, Colloid Surf. B: Biointerfaces 20 (2001) 197.

[6] D.J. McClements, Food Emulsions: Principles, Practice and Techniques, CRC, Press, Boca Raton, FL, 2000

[7] J. Benjamins, J. Lyklema, E.H. Lucassen-Reynders, Langmuir 22 (2006) 6181.

[8] J.L. Ventureira, A.J. Bolontrade, F. Speroni, E. David-Briand, A.A. Scilingo, M.-H. Ropers, F. Boury, M.C. Añón, M. Anton, LWT-Food Sci. Technol. 45 (2012) 1.

[9] A.J. Bolontrade, A.A. Scilingo, M.C. Añón, Colloid Surf. B: Biointerfaces 105 (2013) 319.

[10] AOAC. Association of Official Analytical Chemists Inc., in: S. Williams, V.A. Arlington (Eds.), Official Methods of Analysis, 14 ed., 1984, p. 16, Method 2057.

[11] M. Segura-Nieto, A.P. Barba de la Rosa, O. Paredes López, in: O. Paredes-López (Ed.), Amaranth: Biology, Chemistry and Technology, CRC, Boca Raton, 1994, p. 75.

[12] E.N. Martínez, M.C. Añón, J. Agric. Food Chem. 44 (1996) 2523

[13] W. Krotov, in: R. Millar, L. Liggieri (Eds.), Progress in Colloid and Interface Science: Interfacial Rheology, vol. 1, Brill, Leiden, 2009, p. 3.

[14] W. Loisel, J. Gueguén, Y. Popineau, in: K.D. Schwenke, R. Mothes (Eds.), Food Proteins: Structure and Functionality, VCH, Weinheim, Germany, 1993, p. 320.

[15] L.A. Panizzolo, L.E. Mussio, M.C. Añón, Int. J. Food Prop. 15 (2012) 60.

[16] D.J. Wright, J. Hemmant, J. Sci. Food Agric. 41 (1987) 361. 
[17] M.A. Yu, S. Damodaran, J. Agric. Food Chem. 39 (1991) 1563.

[18] A.H. Martín, M.A. Bos, T. van Vliet, Food Hydrocol. 16 (2002) 63.

[19] J.M. Rodríguez Patino, S. Molina Ortiz, C. Carrera Sánchez, M.R. Rodríguez Niño, M.C. Añón, J. Colloid Interface Sci. 268 (2003) 50.

[20] J.M. Rodríguez Patino, S. Molina, C. Carrera, M.R. Rodríguez Niño, M.C. Añón, J. Colloid Interface Sci. 50 (2003) 268.

[21] A. Hambardzumyan, V. Aguié-Béghin, M. Daoud, R. Douillard, Langmuir 20 (2004) 756

[22] J. Maldonado Valderrama, Caracterización Interfacial de Proteínas y Tensioactivos: Aplicación a Dispersiones Alimentarias, PhD Thesis, Editorial de la Universidad de Granada, Granada, Spain, 2006.

[23] P. Joss, Biochim. Biophys. Acta 375 (1975) 1.

[24] J. Benjamins, E.H. Lucassen-Reynders, in: D. Mobius, R. Miller (Eds.), Studies in Interface Science. 7-Proteins at Liquid Interfaces, Elsevier, Amsterdam, 1998, p. 341.
[25] E.M. Freer, K.S. Yim, G.G. Fuller, C.J. Radke, J. Phys. Chem. B 108 (2004) 3835.

[26] G. Serrien, G. Geeraerts, L. Gosh, P. Joos, Colloids Surf. 68 (1992) 219.

[27] E.H. Lucassen-Reynders, J. Benjamins, V.B. Fainerman, Curr. Opin. Colloid Interface Sci. 15 (2010) 264

[28] J. Lucassen, M. van den Tempel, Chem. Eng. Sci. 27 (1972) 1283.

[29] S. Damodaran, Adv. Food Nutr. Res. 34 (1990) 1.

[30] J.L. Ventureira, E.N. Martínez, M.C. Añón, Food Hydrocol. 29 (2012) 272.

[31] D. Langevin, Adv. Colloid Interface Sci. 88 (2000) 209.

[32] P. Wilde, Curr. Opin. Colloid Interface Sci. 5 (2000) 176.

[33] A. Bhattacharyya, F. Monroy, D. Langevin, J.-F. Argillier, Langmuir 16 (2000) 8727.

[34] K. Malysa, K. Lunkenheimer, Curr. Opin. Colloid Interface Sci. 13 (2008) 150.

[35] A. Sonin, A. Bonfillon, D. Langevin, J. Colloid Interface Sci. 162 (1994) 323.

[36] F.G. Gandolfo, H.L. Rosano, J. Colloid Interface Sci. 194 (1997) 31.

[37] D.A. Kim, M. Cornec, G. Narsimhan, J. Colloid Interface Sci. 285 (2005) 100. 